\title{
Careers and retention of staff in the 21st century world of work: Introduction to the special edition
}

\author{
Authors: \\ Melinde Coetzee ${ }^{1}$ \\ Hugh Gunz ${ }^{2}$ \\ Affiliations: \\ ${ }^{1}$ Department of Industrial \\ and Organisational \\ Psychology, University of \\ South Africa, South Africa \\ ${ }^{2}$ Joseph L. Rotman School of \\ Management, University of \\ Toronto, Canada

\section{Correspondence to:} \\ Melinde Coetzee \\ Email: \\ coetzm1@unisa.ac.za \\ Postal address: \\ PO Box 392, University of \\ South Africa 0003 \\ South Africa \\ How to cite this article: \\ Coetzee, M., \& Gunz, H. \\ (2012). Careers and retention \\ of staff in the 21st century \\ world of work: Introduction \\ to the special edition. SA \\ Journal of Human Resource \\ Management/SA Tydskrif vir \\ Menslikehulpbronbestuur, \\ 10(2), Art. \#505, 4 pages. \\ http://dx.doi.org/10.4102/ \\ sajhrm.v10i2.505
}

C) 2012. The Authors. Licensee: AOSIS OpenJournals. This work is licensed under the Creative Commons Attribution License.
This special edition is dedicated to career and retention issues in the 21st century world of work context. In today's world of globalisation, demographic change and international migration, the workforce is becoming increasingly diverse. This has resulted in a greater variety of knowledge, skills, experiences and attitudes - all of which contribute to the organisation's performance in what has become a highly competitive global business market (Arnold \& Randall, 2010). Organisations are increasingly recognising the value of attracting, developing and retaining staff from all demographic groups in order to improve workforce performance and thus promote their competitive position (Torrington, Hall, Taylor \& Atkinson, 2009).

Shifting trends in the contemporary world of work have also led to a renewed interest in the psychological factors that influence people's commitment to an organisation. De Villiers (2006) further posits that the importance of employee commitment and loyalty has never been more significant than in the contemporary world of work context, where the 'war for talent' is rife and skilled employees have a greater choice of employment, both locally and globally. Joāo (2010) states in this regard that the global skills shortages have led to an increase in career mobility opportunities for the professionally qualified knowledge worker which has brought with it several challenges for talent retention. Organisations that want to retain valuable employees need to try to establish favourable organisational conditions and human resource practices that will address the differing career needs of a diverse workforce (Coetzee \& Schreuder, 2008; Kniveton, 2004; McNeese-Smith \& Van Servellen, 2000).

Economic events such as mergers, acquisitions, or layoffs have led to a loss in job security, a need to develop highly divergent and diverse career paths, shifts in organisational loyalties and an emphasis on career agency (Baruch, 2004; Bentein, Vandenberghe, Vandenberg \& Stinglhamber, 2005; Marshall \& Bonner, 2003; Sinclair, 2009). A more turbulent career context resulted in careers being less ordered and predictable has further heightened researchers' interest in the subjective aspects of career success and satisfaction (Arthur, Khapova \& Wilderom, 2005; Coetzee \& Bergh, 2009; Hall \& Chandler, 2005; Kidd, 2008; Schreuder \& Coetzee, 2011; Sinclair, 2009). However, some authors have suggested that this career turbulence is less than previously believed (Jacoby, 1999; Rodrigues \& Guest, 2010). A new social arrangement of work has led to new conceptions of work life which recognise that a career belongs to the person and not the organisation (Duarte, 2004). As pointed out by Savickas et al. (2009), occupational prospects seem far less definable and predictable, with job transitions more frequent and difficult. They further argue that these changes require workers to develop career-related skills and competencies that differ substantially from the knowledge and abilities required by 20th century occupations.

The contemporary science and practice of Human Resource Management in particular are challenged to produce new research-based knowledge and practical applications of attracting, developing and retaining talent that fits into the new global knowledge-driven society and support relevant career development interventions. The contributions to this special edition on careers and retention attempt to deepen the understanding of and stimulate debate and research on retention challenges in the contemporary world of work, and the psychological career-related factors that influence individuals' decision to stay or leave. Next, we briefly review the contributions of each of the papers comprising this collection.

Career research in organisations has increased in importance since the 1970s, which heralded new directions for career research and practice both nationally and globally. The increasingly complex contexts in which people are pursuing their careers demand the continuous generation and development of knowledge for the benefit of the discipline and practice of careers. In the article, A review of four decades of research in organisational career psychology by academia in South Africa, Dries Schreuder and Melinde Coetzee critically reviewed organisational career research trends in South Africa from 1970 to 2011. They further evaluated these trends in terms of global and present national challenges that require empirical investigation in the contemporary South 
African world of work context. A broad systematic review was carried out to analyse documented academia research $(N=110)$ on careers from 1970 to 2011, which was published in six accredited South African scientific journals. The authors found that much of the research addressed issues pertaining to career theory and concepts, the world of work and career assessment and technology. Career development, professional issues and organisational career interventions in the multi-cultural South African context appear to be under-researched. The insight derived from the findings can be employed by academia and researchers in the field to plan future research initiatives that will contribute to the profession and practice of career guidance and counselling in the contemporary workplace.

One of the inevitable impacts of a difficult economic scene is loss of employment. Finding work can involve more than just finding a job: the newly unemployed person is often forced to consider alternative occupations, involving career exploration. Career decision-making is a stressful matter, leading to what the authors of, The relationship between cognitive ability, emotional intelligence and negative career thoughts: A study of career-exploring adults, describe as negative career thinking. Frans Cilliers and Dennis Dahl explore the extent to which cognitive ability and emotional intelligence (EI) can affect this negative thinking. In their study of unemployed Canadians going through a 16-day career exploration programme, the authors found, surprisingly, that neither cognitive ability nor EI affected the participants' change in negative career thinking after finishing the programme. Higher levels of both did, however, reduce the absolute level of participants' negative career thinking at the end of the programme, suggesting that counsellors working with unemployed people should be trained in helping their clients become more sensitive to their EI, and work on increasing it.

The impact of challenges such as decreased employment opportunities, an increased personal responsibility to keep up with the changes, current skill shortages and demands for retaining talented and skilled staff have led to an emphasis on career meta-competencies to enhance an individuals' employability attributes. In the article entitled, The relationship between the self-esteem and employability attributes of postgraduate business management students, Ingrid Potgieter found that individuals' self-esteem is significantly related to their employability attributes. The results further showed that individuals' biographical characteristics significantly predicted their employability attributes. The findings provide valuable information that can be used in career development support practices in the contemporary work world context.

The changing nature of work and careers that people experience in today's turbulent times produce a sense of insecurity, leading to stress and anxiety. In Hardiness in relation to organisational commitment in the Human Resource Management field, Nadia Ferreira explores the impact of hardiness - defined in the paper as the 'ability to deal resourcefully with challenging and demanding circumstances
- on organisational commitment. A study of 355 employed adults showed that hardiness is indeed associated with higher levels of organisational commitment. Hardy individuals are more likely to control the way they experience events in terms of their own choices of action, framing these events as opportunities to learn and develop. One implication of this, it seems, is a higher level of commitment to their firm, a useful point for human resource specialists to be aware of.

Chantal Olckers and Yvonne du Plessis explore in the article entitled, The role of psychological ownership in retaining talent: A systematic literature review, the construct of psychological ownership by distinguishing it from other work-related attitudes, and clarifying the role that psychological ownership can play in talent retention. Psychological ownership is defined as a state in which individuals feel as though the target of ownership is 'theirs' - thus they refer to the organisation by saying, 'It is mine!'. Based on a comprehensive review of the research literature, the authors concluded that organisations could benefit from understanding psychological ownership as an attitudinal state that leads employees to feel responsible toward the organisation and show stewardship, which can play a role in the retention of talent.

Mariette Coetzee and Jo-Anne Botha study in the article entitled, The languishment of employee commitment in the light of perceptions of fair treatment in the workplace, organisational behaviours that are indicative of employee commitment and whether perceptions of fair treatment in the workplace influence employees' commitment. An exploratory factor analysis identified four factors relating to employee commitment: obedience, job satisfaction, participation and loyalty. The study further found that biographical factors do not have a practical significant effect on employees' commitment, whereas treatment in the workplace does have a significant effect on their commitment. The authors concluded that committed employees engage in specific behaviours and that managers need to pay attention to the way employees are treated in the workplace.

In the article entitled, Turning the tide: Registered nurses' job withdrawal intentions in a Finnish university hospital, Hanna Salminen examines the job withdrawal intentions of younger and ageing nurses and the factors associated with job withdrawal intentions with special reference to job control and perceived development opportunities. The findings showed that $25 \%$ of the nurses had frequently thought about leaving the profession and 19\% of the nurses had frequently thought about taking early retirement. Younger age, low job satisfaction, low organisational commitment, low work ability, skills in balance with present work demands and the potential to carry out more challenging tasks increased the likelihood of occupational turnover intentions. Early retirement intentions were increased by older age, being male, working shifts, low work ability, low job satisfaction and poor job control. The findings emphasise the importance of regularly monitoring nurses' job satisfaction and work ability and offering opportunities to use their skills and 
abilities and to control their work in order to retain them in their profession.

In the article entitled, Does organisational commitment enhance the relationship between job involvement and in-role performance?, Talat Islam, Saif Ur Rehman Khan, Norulkamar Ungku A. Ungku and Ishfaq Ahmed found a weak relationship between job involvement and in-role performance, and that affective and normative commitment act as significant mediators of this relationship. The authors concluded that managers need to recognise the importance of increasing employees' involvement in and commitment to their jobs.

Jeannette van Dyk and Melinde Coetzee found in the article entitled, Retention factors in relation to organisational commitment in medical and information technology services, that employees' satisfaction with retention factors is significantly related to their organisational commitment, and that gender, age, race and tenure groups differed significantly in terms of the variables. Understanding the retention factors that will enhance the organisational commitment of medical and information technology services staff may benefit the organisation who wants to retain their valuable talent. The authors provided valuable pointers for the design of effective retention strategies.

Joy Mohlala, Geoff Goldman and Xenia Goosen studied the challenges faced by a bank's Information Technology (IT) leadership team when retaining employees who have knowledge and skills that are considered core to the bank's purpose of existence and continued success in the article entitled, Employee retention within the Information Technology Division of a South African Bank. The IT industry is currently faced with a shrinking pool of skilled IT employees as a result of the increasing demand for these employees. This increasing demand has put organisations under pressure to start devising retention strategies in order to retain the targeted employees. Based on a qualitative study, high employee turnover was found to be the main contributor of the skills shortages within the IT department of the bank. The non-existence of a proper retention strategy was making it difficult for the leadership team to identify the type of skills that are critical to the organisation and which must be retained. The study findings point to the importance of creating an environment conducive to the retention of IT professionals.

In the article entitled, The relative importance of different types of rewards for employee motivation and commitment in South Africa, Sayyideena Nujjoo and Ines Meyer sought to establish the relationship between intrinsic and different extrinsic rewards with intrinsic motivation and affective commitment. The research literature shows that employees who are more motivated and committed to their organisation are less likely to quit. Rewards management strategies serve to create a motivated and committed workforce. Using the correct types of rewards can thus provide a competitive advantage. The authors found the relationship between the variables to be stronger for intrinsic than for extrinsic rewards and that monetary rewards do not account for the variance in intrinsic motivation above that of non-monetary rewards. On a practical level, the findings suggest that rewards management strategies should focus on job characteristics and designs to increase staff's intrinsic rewards and include non-monetary rewards, such as supportive leadership, to encourage employees' intrinsic motivation and affective commitment.

Jo-Ann Gainsford and Ebben van Zyl developed in the article entitled, The effectiveness of talent management programmes in selected South African organisations, a theoretical framework comprising the essential components of an effective talent management programme in the financial, transport and mining sectors. The study assessed and compared employees' satisfaction with regard to the various components of the current talent management programmes as implemented in the selected organisations. Overall, employees were found to be dissatisfied with the current state of talent management in their respective companies. The authors provided valuable guidelines for improving talent management in the financial, transport and mining sectors.

This interesting collection of theoretical and empirical papers provides intriguing insights into career phenomena that are of significance in today's turbulent economy in general, but also examines issues of specific importance to South African organisations. Career phenomena are fascinating to the scholar because of their complexity and their connectedness with so many different aspects of organisations. For the practitioner, they link to issues that are of fundamental importance to the future of organisations and the lives of the people who comprise them. These papers make many valuable contributions to our understanding of both.

\section{Acknowledgements}

We would like to express our gratitude to all the authors who contributed to this special edition.

\section{Competing interests}

The authors declare that they have no financial or personal relationship(s) which may have inappropriately influenced them in writing this paper.

\section{Authors' contributions}

M.C. (University of South Africa) and H.G. (University of Toronto) both acted as guest editors of the special edition. The introduction to the special edition was jointly written by them.

\section{References}

Arnold, J., \& Randall, R. (2010). Work psychology: Understanding human behaviour in the workplace. (5th edn.). Harlow, Essex: Pearson Education.

Arthur, M.B., Khapova, S.N., \& Wilderom, C.P.M. (2005). Career success in a boundaryless career world. Journal of Organisational Behavior, 26(1), 177-202. http://dx.doi.org/10.1002/job.290 
Baruch, Y. (2004). Transforming careers: From linear to multi-directional career paths. Career Development International, 9(1), 58-73. http://dx.doi. paths. Career Development
org/10.1108/13620430410518147

Bentein, K., Vandenberghe, C., Vandenberg, R., \& Stinglhamber, F. (2005). The role of change in the relationship between commitment and turnover: a latent growth modelling approach. Journal of Applied Psychology, 90(3), 468-482. http://dx.doi. org/10.1037/0021-9010.90.3.468, PMid:15910143.

Coetzee, M., \& Schreuder, D. (2008). A multi-cultural investigation of students' career anchors at a South African higher education institution. SA Journal of Labour Relations, 32(2), 1-11.

De Villiers, R. (2006). Alumni talent: How losing the retention battle can help win the talent war. Civil Engineering, 14(1), 15.

Duarte, M.E. (2004). The individual and the organization: Perspectives of development. Psychologica (Extra-Série), 1, 549-557.

Hall, D.T., \& Chandler, D.E. (2005). Psychological success: When the career is a calling. Journal of Organisational Behavior, 26(1), 155-176. http://dx.doi.org/10.1002/ job.301

Joāo, T.F. (2010). The relationship between perceived career mobility, career mobility preference, job satisfaction and organisational commitment. Unpublished master's thesis, University of South Africa, Pretoria, South Africa.

Jacoby, S.M. (1999). Are career jobs headed for extinction? California Management Review, 42(1), 123-145. http://dx.doi.org/10.2307/41166022

Kidd, J.M. (2008). Exploring components of career well-being and the emotions associated with significant career experiences. Journal of Career Development 35(2), 166-186. http://dx.doi.org/10.1177/0894845308325647
Kniveton, B.H. (2004). Managerial career anchors in a changing business environment. Journal of European Industrial Training, 28(7), 564-573. http://dx.doi. org/10.1108/03090590410549984

Marshall, V., \& Bonner, D. (2003). Career anchors and the effects of downsizing: Implications for generations and cultures at work: A preliminary investigation.
Journal of European Industrial Training, 27(6), 281-291. http://dx.doi. org/10.1108/03090590310479910

McNeese-Smith, D., \& Van Servellen, G. (2000). Age, development and job stages: Impact on nurse outcomes. Outcomes Management for Nursing Practice, 4(2), 97-104. PMid:11111591

Rodrigues, R.A., \& Guest, D. (2010). Have careers become boundaryless? Human Relations, 63(8), 1157-1175. http://dx.doi.org/10.1177/0018726709354344

Savickas, M.L., Nota, L., Rossier, J., Dauwalder, J., Duarte, M.E., \& Guichard, J. et al. (2009). Life designing: A paradigm for career construction in the 21st century. Journal of Vocational Behavior, 75(1), 239-250. http://dx.doi.org/10.1016/j. jvb.2009.04.004

Schreuder, A.M.G., \& Coetzee, M. (2011). Careers: An organisational perspective. (4th edn.). Cape Town: Juta.

Sinclair, V. (2009). Experiencing career satisfaction and career success over the life span. Retrieved February 02, 2010, from http://www.counselling-directory.org. uk/counselloradvice98889.html

Torrington, D., Hall, L., Taylor, S., \& Atkinson, C. (2009). Fundamentals of human resource management. London: Pearson. 